\title{
STUDY OF PETIOLE ANATOMY AND POLLEN MORPHOLOGY OF FIVE SPECIES OF SENNA MILL. FROM BANGLADESH
}

\author{
Mabia Khanom Doty, Parveen Rashid and Kishwar Jahan Shethi* \\ Plant Physiology, Nutrition and Plant Biochemistry Laboratory, \\ Department of Botany, University of Dhaka, Dhaka-1000, Bangladesh
}

Key words: Senna, Anatomy, Trichome, Vascular bundle, Pollen

The genus Senna Mill. is comprised of about 350 species throughout the world(1) and about 11 of them have been reported from Bangladesh to date ${ }^{(2)}$. Most of the species of Senna are traditionally used as medicine for various purposes in Bangladesh and different parts of the world. Senna is a Food and Drug Administration (FDA) approved non-prescription laxative to treat constipation and also to clear bowl before diagnostic tests like colonoscopy. Senna bark and oil extract are used for flavoring purposes. The seeds and leaves are used to treat skin diseases e.g. ringworm and itch ${ }^{(3)}$.

The taxonomy of this plant group is still puzzling because of the extreme morphological variability and ambiguous boundaries between taxa ${ }^{(4)}$. Anatomical features provide characters to supplement the macro-morphological characters of plant species. Foliar anatomical characters such as stomata, trichomes have been found instrumental in solving taxonomic problems in case of Senna $a^{(5)}$. Pollen grain characterization has been utilized with success in taxonomy of both living and fossil

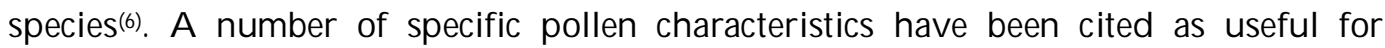
differentiation between closely related plant groups ${ }^{(7)}$. The proper authentication of crude drug material is essential for standards of safety and quality to be maintained. Moreover, such studies will increase the reliability of existing knowledge of taxonomy of Senna species. Therefore, among the 11 species found in Bangladesh five commonly grown species, namely S. alata, S. hirsuta, S. occidentalis, S. sophera and S. tora were selected for detailed anatomical and palynological study during the present research work.

To analyze anatomical structures of petiole and pollen fresh samples were collected from different areas of Dhaka University campus and herbarium specimens were deposited in Dhaka University Salar Khan Herbarium (DUSH). To study the petiole anatomy, third leaf from the base was chosen and petiole around $1 \mathrm{~cm}$ below the laminar base was selected. The sections were stained with safranin and mounted in $20 \%$ glycerin. Transverse sections of petiole were studied using a digital camera (Nikon UFY-11A, Japan) attached with compound light microscope (Nikon ECLIPSE E200) at different magnifications.

*Author for correspondence: <kishwar.botany@du.ac.bd>. 
For scanning electron microscopy (SEM) acetolysis technique ${ }^{(8)}$ for pollen grains had been conducted during the present work. After the pollen grains were acetolyzed, gradual step-by-step dehydration of pollen grains was carried out. The dehydrated pollen grains were then dusted on the smooth surface of an adhesive tape pasted onto the stub. The stubs were then coated with platinum in a sputter coat (JEOL JSM 1100). The coated pollen grains were observed in the SEM (JEOL JSM 5600 LV) and photographed. To measure the anatomical traits ocular micrometer was calibrated against 1 $\mathrm{mm}$ stage micrometer. Average and standard deviation for each parameter were calculated using Microsoft excel 2007.

Petiole anatomy: Petiole of $S$. alata was surrounded by uniseriate epidermis of radially elongated cells with thick cuticle outside of the epidermis. As shown in Fig. 1A the petiole was obovate in shape with two prominent ridges on the adaxial side and in between two ridges the outer area was flattened. In cortex : an outer collenchyma and an inner chlorenchyma, 14 layers of parenchymatous cells were found close to the abaxial side and 2 - 3 layers of parenchymatous cells to the lateral side. 2 - 3 layers of chlorenchymatous cells occurred immediately below the collenchyma cells (Fig. 1A). Wide, parenchymatous pith was present with druse crystals inside the cells of pith. Petiole of S. hirsuta was surrounded by thick cutinized uniseriate epidermis of polygonal shaped cells. The petiole appeared as obovate with two prominent ridges on the adaxial side. In between two ridges the outer area was flattened as S. alata (Fig. 1B). Two types of cells were found in cortex : chlorenchyma and collenchyma. More chlorenchymatous cells occurred in the adaxial surface. 4 - 5 layers of sclerenchymatous cells surrounded the vascular bundles in a continuous form. Sclerenchymatous layer forming crescent like structure surrounded the wing vascular bundles. Wide pith composed of parenchymatous cells (Fig. 1B). Large amount of druse crystals were present in the pith (Fig. 1F). Uniseriate polygonal shaped epidermal layer with thick cuticle was present in the petiole of S. occidentalis. As shown in Fig. 1C shape of the petiole was obovate with two prominant ridges and a prominent groove on the adaxial side (Fig. $1 \mathrm{H}$ ). Two types of cells were found in cortex : chlorenchyma and collenchyma. Same as S. hirsuta many chlorenchymatous cells occurred in the adaxial surface and 4 - 5 layers of continuous layer of sclerenchymatous cells surrounded the vascular bundles. Crescent shaped sclerenchyma layer surrounded the 2 wing vascular bundles (Fig. 1C). A few number of druse crystals were present in the wide, parenchymatous pith. Petiole of $S$. sophera was surrounded by tangentially elongated uniseriate epidermal cells with thin cuticle outside of the epidermis. The petiole appeared in the shape of obovate with two slight ridges on the adaxial side. In between two ridges the outer area was slightly curved (Fig. 1D). Two types of cells were found in cortex : an outer chlorenchyma and an inner collenchyma. More chlorenchymatous cells occurred in the adaxial surface. Five - six layers of sclerenchymatous cells surrounded the vascular bundles. The sclerenchyma patches were 
discontinuous (Fig. 1D). Druse crystals were present in the parenchymatous pith. As shown in Fig. 1E petiole of $S$. tora was surrounded by uniseriate epidermis of barrel shaped cells and thin cuticle outside of the epidermis. The petiole was obovate with two slight swelling on the adaxial side.
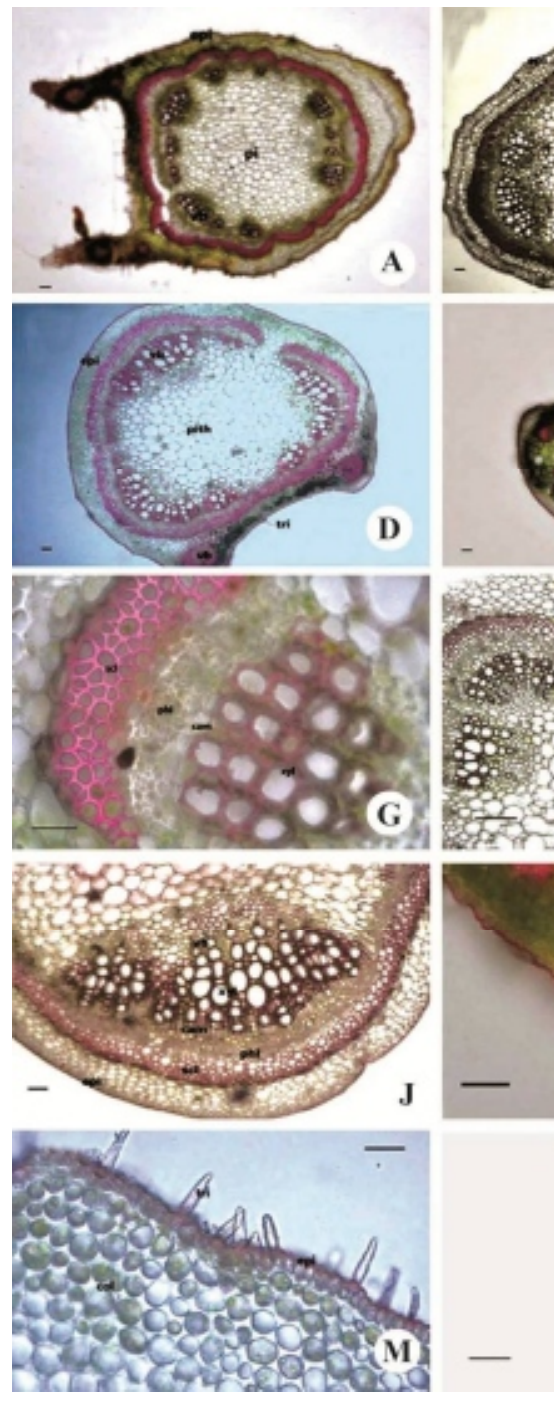

Fig. 1. Transverse section of petiole of mature plant showing whole petiole of (A - E) S. alata, S. hirsuta, S. occidentalis, S. sophera and S. tora at 50X; (F) S. sophera pith with druses crytals at 400X; (G) S. tora vascular area at 400X; (H) S. occidentalis groove and vascular area at proximal side of petiole at 400X; (I) lateral vascular area of S. alata at 400X; (J) distal vascular area at 400X of S. sophera; (K - L) wing vascular areas of $S$. alata and S. sophera respectively at 400X; $(\mathrm{M}-\mathrm{O})$ Trichomes of S. alata, S. hirsuta and S. tora, respectively at 400X where epi $=$ epidermis, $\mathrm{pi}=$ pith, $\mathrm{phl}=$ phloem, $\mathrm{xyl}=$ xylem, $\mathrm{cam}=$ cambium, $\mathrm{col}=$ collenchyma, $\mathrm{scl}=$ sclerenchyma, cry $=$ crystal, $\mathrm{vb}=$ vascular bundle, $\mathrm{col}=$ collenchyma, tri $=$ trichome . Bar $=50 \mu \mathrm{m}$. 
In between two ridges the outer area was more or less flattened. Two types of cells were found in cortex: an outer chlorenchyma and an inner collenchyma. More chlorenchymatous cells occurred in the adaxial surface. Sclerenchyma patches were observed above each vascular bundle forming a cap (Fig. 1G). Pith was wide and composed of parenchymatous cells. Druse crystals were absent in the pith. Symbolic dissimilarity observed in the types and number of vascular bundles of Senna petiole. Petiolar vascular bundles were generally classified in groups according to their position i.e. proximal/dorsal (Fig. 1H), middle/ateral (Fig. 1I) and distal/ventral (Fig. 1J). In addition, in the ridges of the petiolar adaxial side smaller vascular bundles denoted as wing vascular bundles were also observed. Fig. $1 \mathrm{~K}$ showed 3 wing vascular bundles in $S$. alata whereas Fig. 1L showed one wing vascular bundle in S. hirsuta. Variable number of different vascular bundles across the species of Senna have been shown (Table 1). Obovate petiole with 2 ridges and an adaxial wide groove and the main petiolar vasculature in the form of 7 separate vascular bundles: 3 dorsals, 2 laterals and 2 ventrals

Table 1. Comparative analysis of anatomical features of petiole of five species of Senna.

\begin{tabular}{|c|c|c|c|c|c|c|c|}
\hline $\begin{array}{l}\text { Features } \\
\text { of species }\end{array}$ & $\begin{array}{l}\text { Dorsal } \\
\text { vascular } \\
\text { bundle }\end{array}$ & $\begin{array}{l}\text { Ventral } \\
\text { vascular } \\
\text { bundle }\end{array}$ & $\begin{array}{l}\text { Lateral } \\
\text { vascular } \\
\text { bundle }\end{array}$ & $\begin{array}{l}\text { Trichome } \\
\text { type }\end{array}$ & $\begin{array}{l}\text { Wing } \\
\text { vascular } \\
\text { bundle }\end{array}$ & $\begin{array}{l}\text { Wing } \\
\text { type }\end{array}$ & $\begin{array}{l}\text { Sclerenchyma } \\
\text { thickness } \\
(\mu \mathrm{m})\end{array}$ \\
\hline S. alata & 4 & 4 & 4 & $\begin{array}{l}\text { Numerous, } \\
\text { short, non- } \\
\text { glandular }\end{array}$ & 6 & Prominent & $32.06 \pm 1.22$ \\
\hline S. hirsuta & 2 & 2 & 2 & $\begin{array}{l}\text { Numerous, } \\
\text { both non- } \\
\text { glandular } \\
\text { and } \\
\text { glandular }\end{array}$ & 2 & Prominent & $42.46 \pm 2.45$ \\
\hline S. occidentalis & 1 & 2 & 6 & $\begin{array}{l}\text { Rare, } \\
\text { glandular }\end{array}$ & 2 & Prominent & $55.46 \pm 2.45$ \\
\hline S. sophera & 1 & 4 & 0 & $\begin{array}{l}\text { Rare, non- } \\
\text { glandular }\end{array}$ & 2 & Insignificant & $82.33 \pm 1.22$ \\
\hline S. tora & 1 & 0 & 2 & $\begin{array}{l}\text { Rare, non - } \\
\text { glandular }\end{array}$ & 2 & Insignificant & $46.8 \pm 2.12$ \\
\hline
\end{tabular}

Mean value for three observations \pm standard deviation.

in S. occidentalis had been reported by several researches ${ }^{(9-12)}$ contrary to present findings. Prominent ridge was observed in S. alata, S. occidentalis and S. hirsuta whereas it was insignificant in S. tora and S. sophera. Such structure of Senna stem had also been observed by others ${ }^{(9,12)}$. Earlier 2 smaller and one larger vascular bundles in each ridge of the 
petiole of $S$. alata had been demonstrated ${ }^{(13)}$. However, authors observed 4 - 6 vascular bundles in each ridge of $S$. alata petiole. Presence and frequency of different types of trichome is another diagnostic characteristic to distinguish among different plant species $^{(12)}$. Non-glandular and unicellular types of trichome were noticed in S. alata (Fig. 1M), S. tora (Fig. 1O) and S. sophera. Contrarily trichomes were both glandular and nonglandular in S. hirsuta (Fig. 1N) and only glandular in S. occidentalis (Table 1). In contrast to present finding in S. occidentalis thin, mostly unicellular trichome had been reported by several other research works ${ }^{(9-12)}$.

Pollen morphology: Different pollen morphological features are considered as conservative features for the taxonomic assessment of the plants. During the present work, different palynological features namely pollen type, equatorial axis, colpal length and exine ornamentation were examined (Table 2). Polar views of the samples were shown under light microscopy (Figs 2A, 2D, 2G, 2J and 2M) whereas equatorial view and surface orientation was conducted under SEM (Figs 2B-C, 2E-F, 2H-I, 2K-L and 2N-O). All the species showed tricolporate type pollen with difference in the measurements of colpal length and equatorial axis length (Table 2) parallel to other research findings ${ }^{(14-16)}$. In case of exine ornamentation, mainly rugulate and granulate type ornamentation was observed across the species. Similar result in case of S. occidentalis had been reported by others $^{(16)}$. However, in S. occidentalis rugulate-fossulate arrangement was found (Fig. 2I).

Table 2. Pollen parameters of the plant taxa by SEM study.

\begin{tabular}{lllll}
\hline $\begin{array}{l}\text { Name of } \\
\text { Senna species }\end{array}$ & $\begin{array}{l}\text { Pollen } \\
\text { type }\end{array}$ & $\begin{array}{l}\text { Equatorial axis } \\
(\mu \mathrm{m})\end{array}$ & $\begin{array}{l}\text { Length of } \\
\text { colpa }(\mu \mathrm{m})\end{array}$ & $\begin{array}{l}\text { Exine } \\
\text { ornamentation }\end{array}$ \\
\hline S. alata & Tricolporate & $15.29 \pm 0.38$ & $24.14 \pm 1.14$ & Granulate \\
S. hirsuta & $"$ & $26.92 \pm 0.52$ & $30.71 \pm 3.11$ & Rugulate \\
S. occidentalis & $"$ & $32.69 \pm 0.65$ & $43.06 \pm 0.34$ & Rugulate-fossulate \\
S. sophera & " & $23.31 \pm 0.83$ & $40.82 \pm 1.39$ & Granulate \\
S. tora & $"$ & $24.55 \pm 1.7$ & $32.90 \pm 2.99$ & Finely rugulate \\
\hline
\end{tabular}

Mean value for three observations \pm standard deviation.

The pollen morphology of the subfamily Caesalpinioideae had been examined by a number of researchers ${ }^{(17-20)}$. However, it was found that the delimitation of Fabaceae genera on the basis of pollen characteristics is difficult ${ }^{(21)}$. In spite of this, shape, apertural types and exine ornamentation are often found to be significant pollen characters. Tricolporate pollen is the main and basic type found in most eudicots while other aperture types such as 5-colpate, 6-colpate, porate, colporate and pororate are also reported among eudicots(22). 


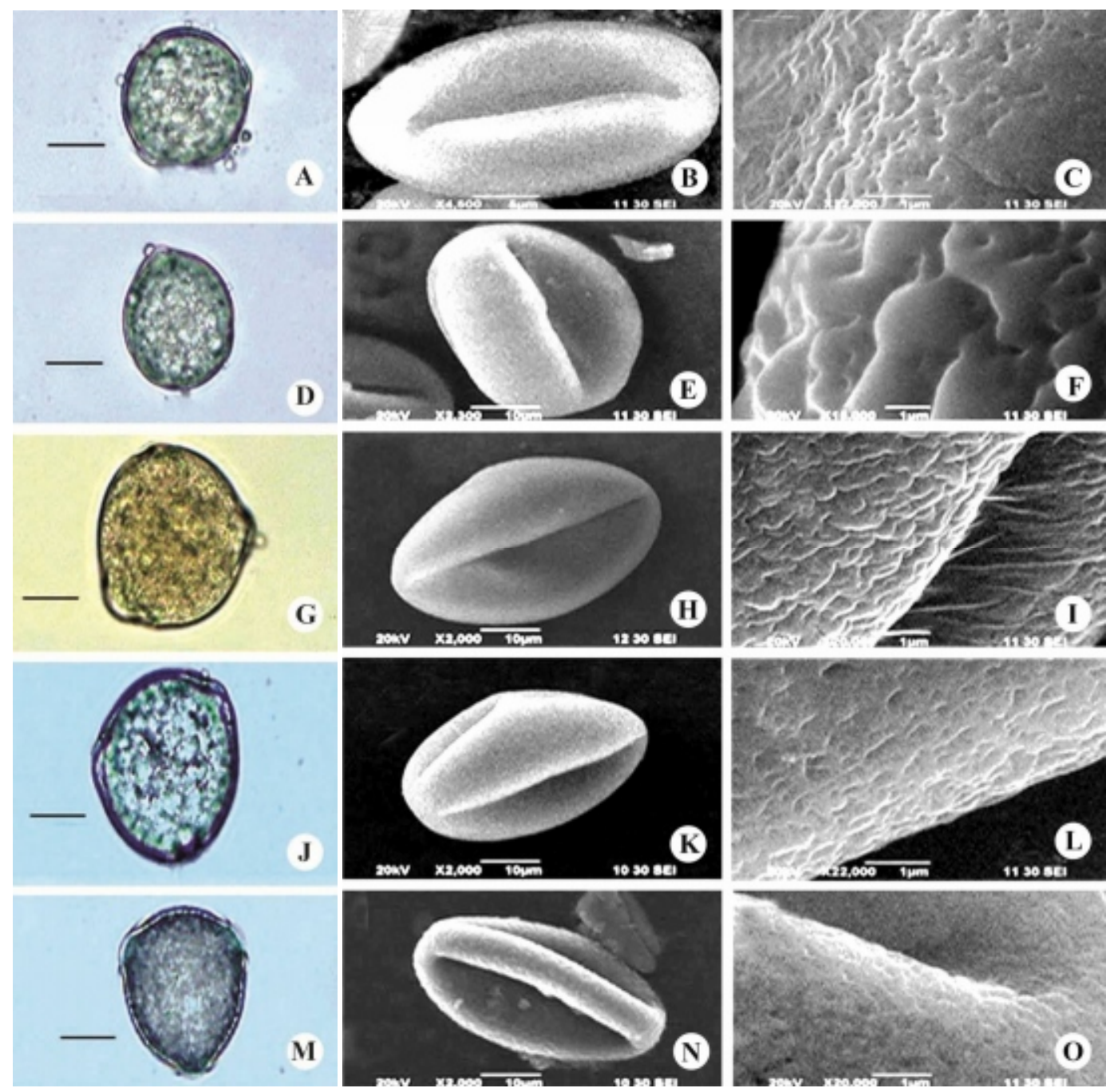

Fig. 2. Under light microscope fresh pollen grains showing polar view where (A) S. alata, (D) S. hirsuta, (G) S. occidentalis, (J) S. sophera and $(\mathrm{M}) \mathrm{S}$. tora $(\mathrm{Bar}=50 \mu \mathrm{m})$. Scanning electron micrograph showing equatorial view and exine ornamentation respectively (B)-(C) S. alata, (E)-(F) S. hirsuta, (H)-(I) S. occidentalis, (K)-(L) S. sophera and $(\mathrm{N})-(\mathrm{O})$ S. tora.

Though a number of attempts were made to describe petiole and pollen micromorphology of different Senna species across the world, this is for the first time to compare and combine five common and important Senna species reported from Bangladesh. Detailed work including anatomy of other plant parts as well as other species of Senna should be considered in future. 


\section{References}

1. Marazzi B, KP Endress, LP de Queiroz and E Conti 2006. Phylogenetic relationships within Senna (Leguminosae, Cassiinae) based on three chloroplast DNA regions : Patterns in the evolution of floral symmetry and extrafloral nectaries. Am. J. Bot. 93(2): 288-303.

2. Ahmed ZU, MA Hassan, ZNT Begum, M Khondker, SMMH Kabir, M Ahmed, ATA Ahmed, AKA Rahman and EU Huque 2008. Encyclopedia of Flora and Fauna of Bangladesh. Angiosperms: Dicotyledons (Balsaminaceae-Euphorbiaceae). Asiatic Society of Bangladesh, Dhaka 7: 546-555.

3. Ghani A 2003. Medicinal Plants of Bangladesh. (2nd edn.) Asiatic Society of Bangladesh, Dhaka, pp. 603.

4. Burkill HM 1995. The Useful Plants of West Tropical Africa. Vol. 2 (2nd edn.) Royal Botanic Gardens, Kew, pp. 654-670.

5. Begum A, MO Rahman and M Begum 2014. Stomatal and trichome diversity in Senna Mill. from Bangladesh. Bangladesh J. Plant Taxon. 21(1): 43-51.

6. De Leonardis W, G Fichera, B Ocampo, G Venora, S Vona and Zizza A 1995. Correlation between pollen grain and seed size in Cicer species. J. Genet. Breed. 49: 21-26.

7. Javady $\mathrm{T}$ and $\mathrm{K}$ Arzani 2001. Pollen morphology of five Iranian olive (Olea europaea L.) cultivars. J. Agric. Sci. Technol. 3: 37-42.

8. Erdtman G 1952. Pollen morphology and plant taxomony. Angiosperms - An Introduction to Palynology. Vol. 1, Almqvist and Wiksell, Stockholm, pp. 539.

9. Nassar MAA, HRH Ramadan and HMS Ibrahim 2013. Anatomical structures of vegetative and reproductive organs of Senna occidentalis (Caesalpiniaceae). Turk J. Bot. 37: 542-552.

10. Saheed S and H Illoh 2010. A taxonomic study of some species in Cassiinae (Leguminosae) in South Western Nigeria using leaf epidermal characters. Nortulae Botanicae Horti. Agrobotanici Cluj-Napoca 38 (1): 21-27.

11. Ogundipe OT, AB Kadiri and OH Adekanmbi 2009. Foliar epidermal morphology of some Nigerian species of Senna (Caesalpiniaceae). Indian J. Sci. Technol. 2(10): 5-9.

12. Shaheen AM 2007. Characteristics of the Stem-leaf transitional zone in some species of Caesalpinioideae (Leguminosae).Turk. J. Bot. 31: 297-310.

13. Mohideen S, K Sasikala and AJ Paru 2005. Pharmacognocy of Cassia alata Linn. leaves. Anc. Sci. of Life 24(4): 192-198.

14. Bhattacharya P, S Biswas and JK Pal 2015. Palyno-taxonomic study of some plant taxa of Fabaceae from Arambagh region of Hooghly district, West Bengal, eastern India. Bioscie. Disc. 6(1): 27-34.

15. Fernandez-Pacella L 2014. Pollen morphology of species of genus Senna (Fabales: Fabaceae) in South-east Ibera, Corrientes, Argentina. Rev. Biol. Trop. 62(2): 769-82.

16. Ferreira K, GA Torres, SM Sousa and ACP Santos 2010. Karyotype, meiotic behavior and pollen features of Senna occidentalis. Biologia 65(5): 789-795. DOI: 10.2478/s11756-0100080-0.

17. Ferguson IK and KJ Pearce 1984. Observations on the pollen morphology of the genus Bauhinia L. (Leguminosae: Caesalpinioideae) in the neotropics. In: Blackmore S, Ferfuson IK (Eds.) Pollen and Spores: Form and function. Academic Press, London. pp. 283-296. 
18. Wunderlin RP 1983. Revision of the arborescent Bauhinias (Fabaceae : Caesalpinioideae: Cercideae) native to Middle American, Ann. Mo. Bot. Gard. 70: 95-127.

19. Graham A and G Baker 1981. Advances in Legumes Systematics. In: Polhill RM, Raven PH (Eds.) Palynology and tribal classification in the Caesalpinioideae. Royal Botanic Gardens, Kew England, pp. 804-232.

20. Ferguson IK 1980. The pollen morphology of the genus Ceratonia (Leguminosae: Caesalpinoideae). Kew Bull. pp. 35.

21. Perveen A and M Qaiser 1998. Pollen Flora of Pakistan-X. Leguminosae (Subfamily: Caesalpinioideae). Tr. J. Botany 22: 145-150.

22. Walker JW and JA Doyle 1975. The Bases of Angiosperm Phylogeny: Palynology. Annals of the Missouri Botanical Garden. 62(3): 664-723. 10.2307/2395271.

(Manuscript received on 17 July, 2019; revised on 26 September, 2019) 